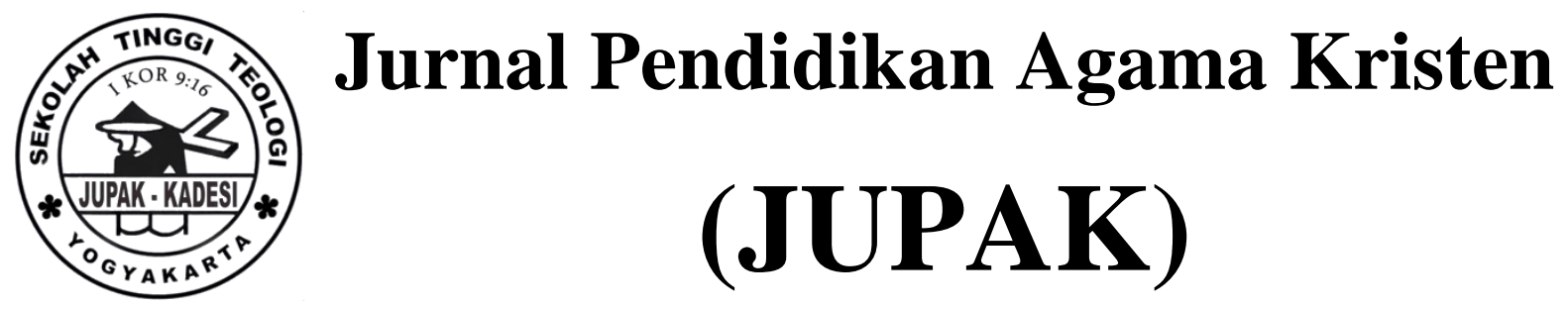

Vol. 1 No. 2 (June 2021) hlm. 108-123

Jurnal Pendidikan Agama Kristen (JUPAK)

e-ISSN 2774-3861

https://ejurnal.sttkadesiyogyakarta.ac.id/index.php/jupak

p-ISSN 2774-6399

https://doi.org/10.52489/jupak.v2i1.25

\title{
Implementasi Best Practice Kristen dalam Pendidikan Agama Kristen di Sekolah Minggu
}

\section{Daniel Supriyadi}

Sekolah Tinggi Teologi Sangkakala, Salatiga, danielsupriyadid544@gmail.com

\section{Recommended Citation}

Turabian $8^{\text {th }}$ edition (full note)

Daniel Supriyadi, "Implementasi Best Practice Dalam Pendidikan Agama Kristen Di Sekolah Minggu," Jurnal Pendidikan Agama Kristen (JUPAK) 1, no. 2 (June 16, 2021): 1, accessed August 6, 2021, https://ejurnal.sttkadesiyogyakarta.ac.id/index.php/jupak/article/view/25.

American Psychological Association $7^{\text {th }}$ edition

(Supriyadi, 2021, p. 1)

Received: 18 May 2021

Accepted: 21 May 2021

Published: 16 June 2021

This Article is brought to you for free and open access by Sekolah Tinggi Teologi Kadesi Yogyakarta. It has been accepted for inclusion in Christian Perspectives in Education by an authorized editor of Jurnal Pendidikan Agama Kristen (JUPAK).

For more information, please contact juniorichson1995@gmail.com 


\begin{abstract}
The implementation of Best Practice in Christian Religious Education in Sunday School is a success that is able to create students who have Christian values in their lives. This needs to be continuously pursued, considering that the purpose of Sunday School learning is to equip Sunday School children with sources of faith, guiding children to achieve a complete personality and reflect the image of God, so that they are able to serve. Using a qualitative descriptive method with a literature study approach, it is concluded that the church needs to pay attention to Sunday school services, namely by providing Sunday school education with best practices in order to prepare the next generation of the church. Sunday school is the embryo of education for the successor of the church. In carrying out Sunday school activities, it is best to fulfill several aspects of Sunday school activities. Several aspects of Sunday School activities, namely, Sunday School as a center for non-formal education, evangelism, an outreach tool, and a channel of blessings.
\end{abstract}

Keywords: Sunday School Best Practice, Christian religious education, Christian Teachers, Ministry

\begin{abstract}
Abstrak
Implementasi Best Practice dalam Pendidikan Agama Kristen di Sekolah Minggu merupakan keberhasilan yang mampu menciptakan murid-murid yang memiliki nilai-nilai Kristiani dalam hidupnya. Hal ini perlu untuk terus di upayakan, mengingat tujuan pembelajaran Sekolah Minggu adalah untuk memperlengkapi anak Sekolah Minggu dengan sumber iman, membimbing anak supaya mencapai kepribadian yang utuh serta mencerminkan gambar Allah, sehingga mereka mampu untuk melayani. Menggunakan metode kualitatif deskritif dengan pendekatan studi literature didapat kesimpulan bahwa gereja perlu memperhatikan pelayanan Sekolah Minggu yaitu dengan menyelenggarakan pendidikan Sekolah Minggu dengan praktik terbaik dalam rangka menyiapkan generasi penerus gereja. Sekolah Minggu merupakan cikal bakal pendidikan bagi penerus gereja. Dalam melaksanakan kegiatan Sekolah Minggu sebaiknya memenuhi beberapa aspek kegiatan Sekolah Minggu. Beberapa aspek dalam kegiatan Sekolah Minggu yaitu, Sekolah Minggu sebagai pusat pendidikan nonformal, pekabaran Injil, alat penjangkau, dan penyalur berkat.
\end{abstract}

Keyword: Best Practice Sekolah Minggu, pendidikan agama Kristen, Guru kristen, Pelayanan

\title{
PENDAHULUAN
}

Pendidikan Agama Kristen (PAK) merupakan bagian dari pelayanan gereja yang semestinya dilaksanakan. Dalam pelaksanaannya Alkitab merupakan satu-satunya sumber pengajaran yang disampaikan. Boelke mengungkapkan bahwa, "Pendidikan Agama Kristen adalah pemupukan akal orang-orang percaya dan anak-anak mereka dengan Firman Allah di bawah bimbingan Roh Kudus melalui sejumlah pengalaman belajar yang dilaksanakan gereja” (Boehlke, 2009, p. 413). Tujuan PAK merupakan usaha untuk membentuk dan membimbing peserta didik agar tumbuh hingga mencapai kepribadian yang utuh serta mencerminkan gambar Allah yang memiliki sifat kasih dan ketaatan kepada Tuhan. Hal ini sejalan dengan pendapat Groome yang mengatakan bahwa, "tujuan PAK adalah untuk 


\section{Daniel Supriyadi}

memampukan orang-orang hidup sebagai orang-orang Kristen, yakni hidup sesuai Iman Kristen"(Groome, 2017, p. 48). Dengan begitu PAK memiliki peran penting dalam pertumbuhan Iman Kristen.

Adapun tujuan lain dalam PAK adalah untuk melibatkan semua jemaat, untuk melaksanakan pelayanan. Boelke mengatakan bahwa, "PAK bertujuan untuk memperlengkapi mereka dengan sumber iman, khususnya pengalaman berdoa, Alkitab, dan rupa-rupa kebudayaan sehingga mereka mampu melayani sesamanya termasuk masyarakat dan negara serta mengambil bagian secara bertanggung jawab dalam persekutuan orang Kristen, yaitu gereja "(Boehlke, 2009). Sehingga setiap jemaat dapat mengambil bagian pelayanan sesuai dengan bidangnya tanpa harus tampil di mimbar.

Selain dilaksanakan disekolah, Pendidikan Agama Kristen juga dilaksanakan di gereja, dan keluarga. Pada hakekatnya keluarga adalah tempat pertama bagi anak untuk mengenal iman Kristen tersebut. Orang tua bertanggung jawab memberi kesaksian iman Kristen kepada anak dan mengajarkan supaya anak menghidupinya (Boehlke, 2009). Anak yang menghidupi nilai-nilai kekristenan akan bertumbuh menjadi pribadi yang mengerti agama dan meneladani setiap ajaran agama yang ada di dalamnya. Gereja juga sama dengan keluarga dan sekolah dimana gereja berperan untuk membentuk karakter anak, agar anak memiliki kepribadian yang baik serta lebih mengalami pengenalan akan Kristus dalam hidupnya. Gereja yang menjadi utusan Allah yang bertanggung jawab atas iman dan kehidupam rohani dari anakanak tersebut, serta harus bertanggung jawab sampai satu hari kelak anak-anak ini dapat bertanggungjawab atsas iman dan kehidupan rohani mereka secara mandiri (Homrighausen \& Enklaar, 2018, p. 137).

Gereja mempunyai kegiatan yang beraneka ragam salah satunya adalah Sekolah Minggu. Pembelajaran yang dilaksanakan dapat menggunakan metode pembelajaran yang bermacam-macam agar anak dapat menerima nilai-nilai yang ditanamkan gereja. Pendidikan agama kristen yang didapatkan anak di gereja bisa melalui kebaktian, dan di dalam kebaktian itu gereja wajib memberitakan Firman Tuhan dan wajib menunjukan kasih Kristus, memberikan pendidikan, dan pengajaran (Homrighausen \& Enklaar, 2018). PAK memiliki peran yang penting bagi fungsi gereja, dimana PAK merupakan pendidikan yang semestinya ditanggung dan dilaksanakan oleh gereja. Maka gereja dapat mempersiapkan bahan pengajaran yang efektif agar dapat membawa generasi gereja pada kesiapan yang lebih matang. Disamping itu perlunya pelaksanan atau praktik terbaik dalam PAK di gereja juga semestinya dilaksanakan supaya pencapaian dalam pendidikan lebih maksimal. Praktik 


\section{Daniel Supriyadi}

terbaik (Best Practice), adalah formula dan prosedur yang telah dibuktikan kesuksesannya dalam dunia praktik dunia nyata (Waspada, 2012). Dalam penelitian ini Best Practice yang dimaksud adalah formula dan prosedur yang telah di buktikan kesuksesannya dalam pelaksanaan Pendidikan Sekolah Minggu anak di gereja. Berkaitan dengan fenomena yang terjadi maka penulis meneliti bagaimanakah implemantasi Best Practice dalam penyelenggaraan Pendidikan Agama Kristen anak Sekolah Minggu. Berdasarkan rumusan masalah diatas, penelitian ini mempunyai tujuan untuk: Mengetahui bagaimana implementasi Best Practice bagi Pendidikan Agama Kristen anak Sekolah Minggu

\section{METODE}

Untuk menjawab pertanyaan bagaimana implemantasi Best Practice dalam penyelenggaraan Pendidikan Agama Kristen anak Sekolah Minggu. Maka penulis menggunakan metode penelitian pustaka dengan pendekatan kualitatif deskriptif (Zaluchu, 2020) (Umrati \& Wijaya, 2020, p. 12). Data-data implementasi dari best practice di kaji setelah terumuskan konsep implementasinya maka penulis menerapkannya bagi sekolah minggu. Penulis juga memasukan literature pustaka terbaru serta menggunakan referensi terbitan jurnal OJS untuk menambah penelitian pustaka ini dalam menelusuri topik tersebut. Sehingga hasil studi dari implementasi Best Practice bagi Pendidikan Agama Kristen anak Sekolah Minggu dapat menjadi pertimbangan dalam memberikan warna pengajaran bagi generasi anak gereja.

\section{PEMBAHASAN}

\section{Best Practice Dalam Dunia Pendidikan}

Best Practice dalam dunia pendidikan merupakan cara yang digunakan untuk mendeskripsikan Pengalaman atau pelaksanaan terbaik mengenai keberhasilan dalam melaksanakan program pendidikan. Hal ini sejalan dengan yang diungkapkan oleh Setiawaty dalam penelitiannya mengenai Best Practice, keberhasilan daripada pelaksana pembelajaran adalah ketika lulusan yang dicetak siap untuk bekerja.(Setiawaty, 2017) Untuk mencetak lulusan yang siap bekerja maka, pendidikan yang ditempuh lebih di tekankan pada kurikulum yang di kembangkan dan praktik yang diberikan kepada setiap peserta didiknya.(Setiawaty, 2017)

Dalam hasil penelitiannya Setiawaty menjelaskan bahwa, waktu pendidikan di SMK PIKA Semarang dilaksanakan selama 4 tahun. Tahun pertama sampai ketiga (Kelas X, XI dan XII) pembelajaran teori dan praktik dilakukan di sekolah dan tahun keempat (Kelas XIII) 
siswa prktik kerja industri (prakrin). Pembelajaran praktik dipimpin langsung oleh Wakasek IV yang bertanggung jawab membuat kurikulum praktik, pembelajaran, pengelolaan bengkel, instruktur dan siswa-siswa praktik. Kurikulum praktik dikelompokkan menjadi dua, kurikulum praktik pertukangan dan praktik menggambar yang masing-masing dibimbing oleh instruktur praktik dan instruktur gambar (Setiawaty, 2017).

\section{Best Practice dalam Pendidikan Agama Kristen (PAK)}

Best Practice dalam PAK merupakan keberhasilan dalam Pendidikan Agama Kristen yaitu mampu menciptakan pribadi yang memiliki nilai-nilai Kristiani dalam hidupnya. Serta berkepribadian baik sehingga mampu menjadi dampak bagi lingkungannya. Elisabeth mengungkapkan bahwa "keberhasilan dalam penyelenggaraan PAK adalah membentuk pribadi anak usia dini dengan nilai-nilai Kristiani dan nilai-nilai yang ada di masyarakat serta membantu anak agar tumbuh menjadi pribadi yang matang dan mandiri” (Elisabeth, 2009, p. 8).

Dalam pelaksanaan pembelajaran PAK seyogyanya dilaksanakan sesuai dengan prosedur yang ada, menggunakan metode pengajaran tepat, serta melakukan inovasi pada praktiknya. Dengan sumber SDM yang berkualitas maka keberhasilan dapat dicapai dengan maksimal. Keberhasilan dalam pelaksanaan PAK dapat dicapai dengan memiliki guru PAK yang berkomitmen melayani. Selain itu kerja sama antara guru dan para murid juga menentukan keberhasilan dalam pelaksanaan pembelajaran (Leo, 2008, p. 5). Seorang guru harus pandai dalam menggunakan beberapa cara mengajar supaya pengajaran yang dilaksanakan berhasil.

\section{Konsep dan Hakikat Sekolah Minggu}

Sekolah Minggu merupakan pendidikan yang diselenggarakan oleh gereja dengan sistem pengajaran sesuai Alkitab untuk membentuk anak mengerti akan ajaran dan nilai-nilai kekristenan. Baskoro dan Hermawati mengungkapkan bahwa Sekolah Minggu adalah pendidikan non-formal yang diterapkan dalam suatu komunitas gereja kristen untuk mengajarkan agama bagi jemaat kategori anak-anak (Baskoro \& Hermawati, 2011, p. 5). Sebagai pendidikan non-formal, Sekolah Minggu merupakan bentuk pengajaran bagi anakanak jemaat, yang dilakukan bersama dengan kegiatan-kegiatan ibadah gereja. Materi yang disampaikan adalah seputar isi Alkitab (Vidyarini \& Priyowidodo, 2014). Julita; dkk juga mengungkapkan bahwa, pelajaran yang diajarkan dalam Sekolah Minggu termasuk di 


\section{Daniel Supriyadi}

dalamnya dengan menghafal ayat-ayat tertentu dan lagu-lagu rohani (Mamangkey et al., 2013).

\section{Peran dan Fungsi Sekolah Minggu}

Sekolah Minggu sebagai pendidikan anak dalam gereja perlu menjadi perhatian, peran dan fungsi dari Sekolah Minggu merupakan aspek yang penting. Peran dan fungsi sekolah minggu merupakan dua aspek yang saling berkaitan. Aspek-aspek tersebut antara lain: sebagai pusat pendidikan non-formal, ujung tombak pekerjaan penginjilan, alat penjangkau dan penyalur berkat (Leo, 2008).

\section{Pusat Pendidikan Non-formal}

Sebagai pusat pendidikan Non-formal, Sekolah Minggu merupakan hakiki tangan gereja untuk mendewasakan kehidupan rohani murid dan menyiapkan murid menjadi pelayan dan pemimpin gereja (Leo, 2008). Melalui setiap kegiatan dalam sekolah minggu maka di harapkan setiap anak dapat mengalami pertumbuhan secara rohani, sehingga mereka megalami perubahan dalam tingkah laku mereka dan siap untuk menjadi penerus gereja.

\section{Ujung Tombak Pekabaran Injil}

Sebagai ujung tombak pekabaran Injil, Sekolah Minggu harus dipelihara dan dimanfaatkan secara maksimal (Leo, 2008). Karena kemajuan dan perkembangan gereja dipengaruhi oleh keberhasilan dalam pekabaran Injil. Oleh sebab itu Sekolah Minggu sebagai calon penerus gereja harus menjadi pusat perhatian.

\section{Sarana dan Alat Penjangkau}

Alat penjangkau yang efektif berupaya menciptakan kegiatan yang diarahkan untuk memenuhi kebutuhan dan untuk menarik target individu yang akan dijangkau (Leo, 2008). Dalam setiap kegiatan yang dilaksanakan dalam sekolah minggu sebisa mungkin dapat menjadi perhatian bagi lingkungan gereja.

\section{Penyalur Berkat}

Kehadiran Sekolah Minggu dalam gereja harus dirasakan berkatnya oleh masyarakat sekitar yang mempunyai latar belakang dan kehidupan yang beraneka ragam (Leo, 2008). 


\section{Daniel Supriyadi}

Berkat-berkat yang diberikan kepada masyarakat sekitar dapat berupa benda, doa, ataupun melalui kegiatan-kegiatan yang dapat membangun dan memotivasi masyarakat sekitar.

\section{Tujuan Sekolah Minggu}

Dalam buku yang ditulis oleh Paulus Lie disebutkan bahwa tujuan gereja melaksanakan Sekolah Minggu adalah untuk: Pertama, Mewariskan iman (Yesus Kristus adalah Juru Selamat dunia). Kedua, Membina warga jemaat. Ketiga, Regenerasi umat (agar gereja terus ada dan berkembang dengan baik) (Lie, 2003, p. 110).

\section{Best Practice dalam Pendidikan Agama Kristen di Sekolah Minggu}

Sekolah Minggu sebagai pendidikan non-formal, semestinya melaksanakan pembelajarannya dengan baik. Untuk melaksanakan pembelajaran dengan baik maka program-program pendidikan yang di siapkan juga baik. Best praktice yang dilakasanakan dalam pengajarannya juga menjadi acuan bagi keberhasilan dalam pelaksanaan Sekolah Minggu. Best Practice dalam sekolah minggu terdapat beberapa aitem :

\section{Kurikulum dan Bahan Ajar}

Dalam pelaksanaan kegiatan PAK Sekolah Minggu dibutuhkan adanya kurikulum dimana dengan adanya kurikulum sebuah kegiatan Sekolah Minggu mempunyai pedoman dalam pelaksanaan Sekolah Minggu. Dalam jurnal Junihot M. Simanjuntak dikatakan bahwa kurikulum merupakan rencana belajar yang ditempuh peserta didik bersama dengan guru untuk mewujudkan tujuan yang ditetapkan (Simanjuntak, 2014). Dengan adanya kurikulum pelaksanaan Sekolah Minggu mempunyai alat interaksi dalam kegiatan belajar mengajar. Dalam buku Sutanto Leo yang berjudul Kiat Sukses Mengelola dan Mengajar Sekolah Minggu, Wychoff mengatakan "Kurikulum adalah alat komunikasi yang direncanakan dengan sangat hati-hati, yang digunakan oleh gereja dalam bidang pengajarannya agar iman dan hidup Kristen dapat dikenal, diterima, dan hidup" (Leo, 2008). Dan juga bertujuan mengembangkan dan menumbuhkan iman, sikap, dan tindakan sesuai dengan kesaksian Alkitab (Setiyowati \& Arifianto, 2020).

Dalam kurikulum terdapat adanya bahan ajar, pelaksanaanya PAK Sekolah Minggu bahan ajar juga diperlukan. Materi yang akan disampaikan kepada setiap anak juga disesuaikan. Maka dari itu bahan ajar harus di perhatikan oleh setiap guru atau pengajar supaya anak memiliki pemahaman yang semestinya. Dalam buku Pendidikan Agama Kristen, 


\section{Daniel Supriyadi}

Homrighausen dan Enklar mengungkapkan bahwa pengajaran tentang Alkitab harus di sesuaikan dengan umur murid dan disampaikan dengan memakai cara yang efektif (Enklaar \& Homrighausen, 2011, p. 70).

\section{Metode Mengajar}

Dalam PAK metode adalah suatu pelayanan, suatu pekerjaan aktif, yang kita lakukan bagi Firman Tuhan dan bagi sesama manusia, supaya kedua pihak itu bertemu satu sama lain (Enklaar \& Homrighausen, 2011). Penyampaian materi PAK Sekolah Minggu perlu adanya metode. Dengan metode yang tepat maka pembelajaran atau materi yang disampaikan akan mudah diterima oleh peserta didiknya. Ada beberapa metode yang dapat dipakai dalam pembelajaran di Sekolah Minggu. Bhoelke Dalam buku yang ditulis oleh Daniel Nuhamara, menyebutkan beberapa metode yang dapat digunakan antara lain, metode ceramah, menghafalkan, dialog, studi kasus, perjumpaan, perbuatan simbolis, dan metode cerita (Nuhamara, 2009, p. 138). Setiap guru dapat menggunakan metode yang sesuai untuk pembelajaran yang dilaksanakan. Sebab Strategi dan model pembelajaran Yesus yang diaktualisasi dalam dunia pendidikan mampu memecahkan persoalan dalam kehidupan seharihari dalam meningkatkan pendidikan (Arifianto et al., 2021).

\section{Fasilitas Sekolah Minggu}

Untuk menunjang pelaksanaan PAK Sekolah Minggu fasilitas juga diperlukan untuk mendukung jalannya Sekolah Minggu. Fasilitas seperti musik juga menjadi perhatian dalam pelaksanaan Sekolah Minggu, musik memiliki arti dan peranan yang penting di Sekolah Minggu karena: Satu, Melalui musik anak dapat mengembangkan pemahamannya mengenai Tuhan, dirinya dan orang lain. Dua, Anak dapat ditolong secara intensif menemukan kualitas kesetiaannya kepada Tuhan secara lebih baik (Kadarmanto \& Ruth S, 2005, p. 133).

Dengan musik dapat terjadi dialog dan semua peserta dapat turut ambil bagian di dalamnya. Walaupun semua orang tidak dapat menyanyi atau memainkan instrumen musik, namun semua dapat mengikuti iramanya atau dapat membuat gerakan yang ditimbulkan oleh musik tersebut. Lebih dari itu, musik dapat mengatasi hambatan perbedaan usia atau generasi yang ada dalam kelompok dan menjadi jembatan yang baik atara generasi yang berbeda, sehingga keduannya dapat belajar bersama dalam satu dialog. Dengan demikian, Injil yang disampaikan secara lisan dapat pula disampaikan melalui lagu-lagu yang dinyanyikan. 


\section{Daniel Supriyadi}

Alat peraga dalam pembelajaran juga menunjang untuk pelaksanaan kegiatan pebelajaran. Dengan adanya alat peraga kegiatan belajar-mengajar yang dilaksanakan akan lebih menarik. Penyampaian materi dalam pembelajaran akan mudah di terima oleh peserta didik, sehingga diharapakan materi yang disampaikan akan mudah diingat. Nana Sudjana mengungkapkan bahwa, dalam proses belajar-mengajar alat peraga digunakan dengan tujuan membantu guru agar proses belajar siswa lebih efektif dan efisien (Sudjana, 2009, p. 98).

\section{Model atau desain Sekolah Minggu}

Model dalam geiatan Sekolah Minggu harus ditentukan oleh guru demi tercapainya keberhasilan dalam pendidikan yang diberikan. Guru tidak boleh asal dalam melaksanakan Sekolah Minggu. Paulus Lie mengungkapkan bahwa, desain Sekolah Minggu seharusnya dimulai dari memahami keinginan dan kebutuhan anak, dan dirancang khusus untuk mereka (Lie, 2003). Memahami setiap kebutuhan anak dan setiap latar belakang dari masing-masing anak didik adalah tugas dan tanggung jawab yang dimiliki oleh guru Sekolah Minggu. Agar guru dapat memberikan fasilitas pendidikan sesuai kebutuhan anak, maka dalam pelaksanaanya perancangan kegiatan Sekolah Minggu perlu di perhatikan supaya dalam pelaksanaannya dapat berjalan dengan baik. Mengenai hal ini ada beberapa pelaksanaan dalam Sekolah Minggu yang di paparkan oleh, Homrighausen dan Enklar antara lain: Satu, Batas umur. Segala bagian pengajaran agama kita harus diatur menurut batas-batas umur tertentu. Jadi penetapan batasan umur harus sesuai dengan keadaan jemaat dan perkembangan akal anak-anak didik kita. Dua, Waktu berkumpul. Soal ini khususnya mengenai Sekolah Minggu. Sekolah minggu itu dapat dilaksanakan sebelum kebaktian umum atau segera sesudahnya, ataupun di waktu sore.

Sering kali diadakan apa yang disebut "kebaktian gabungan", yang menghubungkan pelajaran Sekolah Minggu dan kebaktian umum serta mengikuti ibadah rayon. Tiga, Tempat berkumpul. Dalam gedung-gedung gereja yang baru, biasanya ada ruang-ruang tersendiri untuk megadakan perkumpulan atau pelajaran. Jadi, jika pada kita ada beberapa ruang di bilik di samping ruang kebaktian, haruslah kita merancangkan bagaimana kita mempergunakan ruang-ruang lain itu bagi pelaksanaan PAK. Apabila dalam sebuah gereja hanya ada satu ruang saja, ialah tempat kebaktian, lebih perlu lagi kita memikirkan dan merancangkan cara bagaimana kita menempatkan pada kelas-kelas berdasarkan usia anak Sekoah Minggu atau kelompok-kelompok pelajaran Alkitab tersebut dalam ruangan yang ada. 
Empat, Persediaan rencana pelajaran. Dalam hubungannya dengan ini sangat penting dilaksanakannya perancangan materi dan bahan ajar, pertemuan ini dapat di laksanakan tiab bulan oleh semua guru PAK. Pertemuan itu hendaknya disiapkan dan dipimpin dengan mencurahkan segenap tenaga agar jam-jam permusyawaratan dan pelajaran bersama ini berjalan dengan baik. Sehingga semua guru-guru Sekolah Minggu dapat mempersiapkan materi dengan baik pada minggu-minggu berikutnya. Lima, Organisasi PAK. Hal ini juga menuntut perancangan, supaya jangan organisasi dan pimpinan pekerjaan ini diatur dengan sembarangan saja. Sebab banyak persoalan yang perlu di perhatikan, siapa yang menjadi pemimpin umum? Siapa yang merupakan panitia umum bagi PAK dalam jemaat? Siapa yang memperhatikan bagian khususnya? Bagaimana peraturan yang ada dalam Sekolah Minggu.

Enam, Pembagian waktu pelajaran. Jika waktu Sekolah Minggu yang dilaksanakan tepat satu jam lamanya maka waktu selama enampuluh menit itu harus dipakai dengan seefektif mungkin; jadi, berapa lama untuk pembukaan bersama, untuk cerita atau pelajaran, untuk berdoa dan bernyanyi, untuk menutup kegiatan, dan lain sebagainya harus di rancang denagan teliti supaya kegiatan dapat berjalan dengan efektif. Tujuh, Hari-hari raya. Acaranya yang istimewa dan segala hal-istimewa yang harus diingat dan dikerjakan sebagai persediaan bagi pesta semacam itu menuntut perancangan yang seksama pula (Enklaar \& Homrighausen, 2011). Diharapkan dalam setiap acara hari raya anak-anak Sekolah Minggu mendapatkan pemahaman yang baru dalam hidupnya.

\section{Peran Penting Guru Sekolah Minggu}

Guru Sekolah Minggu merupakan figur pembelajar bagi peserta didiknya dan memilikki tugas serta tanggung jawab dalam menentukan masa depan dari sebuah gereja. Seorang Guru tidak boleh berfokus kepada kepentingan diri sendiri karena dapat merusak tatanan keserupaan manusia dengan Kristus (Sitanggang et al., 2020, p. 29). Gereja akan menjadi seperti apa, tidak lepas dari tanggung jawab guru Sekolah Minggu untuk memberikan pembelajaran kepada anak didiknya. Guru adalah teladan dan mentor anak-anak, karena pendidikan tidak pernah hanya tentang mengajarkan dan mempelajari keahlian hitung menghitung atau kesusastraan (Edlin, 2015, p. 204). Guru merupakan sosok yang paling berperan dalam dunia pendidikan, apalagi sebagai guru Sekolah Minggu mereka memegang peranan yang penting. Berdasarkan penjelasan Dien Sumiyatiningsih, dalam tatanan sekolah maupun gereja, guru sebagai pendidik mempunyai kedudukan yang sangat penting dan istimewa (Sumiyatiningsih, 2012, p. 43). Dan juga merupakan Pendidikan Kristen yang 


\section{Daniel Supriyadi}

memiliki landaan teologis yang kuat dalam Perjanjian Baru, yaitu teladan Tuhan Yesus Sang Guru Agung sendiri (Purwoto et al., 2020).

Guru memiliki tugas bagi pelaksanaan PAK Sekolah Minggu karena di samping dia melaksanakan tugas dan tanggung jawabnya dia juga menjalankan tugas pelayanan. Guruguru Kristen haruslah guru yang berdedikasi penuh (purna waktu) dalam pelaksanaan pendidikan Kristen sehingga penggembalaan proses pendidikan Kristen dapat berlangsung dengan baik (Tung, 2015, p. 92). Untuk mencapai keberhasilah dalam Sekolah Minggu maka di butuhkan sosok figur pengajar atau guru yang loyal dengan pekerjaannya. Antara lain:

\section{Sebagai Seorang Agen Pembentuk Karakter dan Kerohanian}

Seorang guru Sekolah Minggu harus memiliki beberapa kriteria antara lain: Pertama, Mengalami pertobatan. Sekolah Minggu bukan hanya berbicara tentang kegiatan rutin yang harus di laksanakan setiap minggu, yang menjadi perhatian pentingnya adalah bagaimana pembinaan karakter sehingga nilai-nilai yang sesuai pengajaran Kristen tertanam dalam diri anak. Seorang guru Sekolah Minggu harus seorang yang telah dilahirkan kembali (Tong, 1995, p. 23). Dua, Takut akan Tuhan. Setiap guru Sekolah Minggu yang memberikan pengajaran, diharapakan mereka orang-orang yang mau menjalankan tanggung jawabnya. Guru kristen perlu terus-menerus menyerahkan dirinya dan bahkan teknik pengajarannya, kepada Allah untuk Dia urapi menjadi berkat bagi anak didik (Sijabat, 1994, p. 167).

Tiga, Sehat jasmani dan rohani. Kesehatan baik jasmani dan rohani merupakan hal yang penting bagi seorang guru. Dalam jurnal Peran gereja dalam Pendidikan Nasional Darmawan mengatakan bahwa, untuk dapat mencapai tujuan menjadikan manusia menjadi manusia yang beriman dan bertakwa kepada Tuhan, maka terlebih dahulu guru-guru harus sehat jasmani dan rohani (Darmawan, 2016). Seorang guru mempunyai pengalama rohani, batinnya dijamah oleh Roh Kudus (Enklaar \& Homrighausen, 2011). Empat. Berkomitmen. Guru perlu senantiasa berupaya meningkatkan pengetahuan dan keterampilan mengajar atas dasar motivasi yang jujur dan komitmen hidup kepada Allah. memiliki dan memelihara komitmen (penyerahan) hidup kepada Yesus Kristus yang adalah sentral dalam perjalanan iman setiap orang percaya (Enklaar \& Homrighausen, 2011). Lima, Bertumbuh dalam Kristus. Guru Kristen adalah orang yang memberi dirinya secara penuh kepada Yesus Kristus, percaya dan menyambut sepenuhnya kedudukan dan peran Yesus sebagai Tuhan, Juruselamat, dan Raja atas hidupnya (Nainggolan, 2006, p. 31). 


\section{Tugas dan Tanggung Jawab Guru}

Sebagai seorang pendidik guru Sekolah Minggu memiliki tugas dan tanggung jawab. Guru memegang peranan penting dalam proses belajar mengajar (Prajnamitra et al., 2020, p. 2). Pencapaiana keberhasilan dalam Sekolah Minggu di tentukan apabila seorang guru dapat melaksanakan tugas dan tanggung jawabnya dengan baik. Tugas sebagai seorang guru Sekolah Minggu antara lain: Satu, Mengajar. Yang dinamakan dengan mengajar merupakan suatu proses pembelajaran dimana dalam prosesnya, guru harus mampu mewujudkan adanya perubahan dalam diri peserta didiknya, baik perubahan tingkah laku maupun pemahaman yang dimiliki. Metode-metode mengajar yang dapat digunakan atara lain: metode kuliah atau ceramah, metode bercerita, metode percakapan atau dikusi, metode lakon atau sandiwara, metode penyelidikan, metode audiovisual, metode menghafal, metode bertanya, metode sharing, metode renungan, metode, cerdas cermat Alkitab yang kreatif, metode cerita gambar hasta karya, metode studi kasus, metode kunjungan lapangan, metode simulasi (Nainggolan, 2006). Dua, Menggembalakan. Guru Sekolah Minggu selain sebagai pengajar dia juga merupakan murid Kristus yang harus meneladani dari sikap Yesus yang merupakan guru dan gembala, sebagai seorang gembala maka Ia meggembalakan, menjaga bahkan juga merawat dan memperhatikan setiap dombanya dengan sepenuh hati. Guru menjadi seorang gembala bagi murid-muridnya (Enklaar \& Homrighausen, 2011). Ketiga, Penerjemah, Dalam setiap pengajaran perlu adanya penjelasan mengenai setiap pelajaran ataupun materi yang disampaikan, sebagai seorang pendidik maka haruslah mampu memberikan penjelasan mengenai materi yang disampaikan supaya dapat diterima setiap peserta didiknya sehingga pembelajaran terdapat komunikasi yang interaktif. Pendidik dalam pengajaran PAK jauh lebih efektif bila mampu berperan sebagai penerjemah, berperan sebagai penolong untuk memfasilitasi agar para pribadi (peserta didik) saling berkomunikasi (Sumiyatiningsih, 2012).

Keempat, Tugas dalam bidang kemasyarakatan, artinya guru hendaknya mampu menjadikan masyarakat yang berilmu pengetahuan, menuju pembentukan manusia seutuhnya (Syatra, 2013, p. 61). Kelima, Tugas dalam bidang kemanusiaan, artinya guru mencerminkan dirinya kepada anak sebagai orang tua kedua (Syatra, 2013). Guru tidak hanya berperan sebagai pengajar saja yang hanya memberikan tugas dan materi, namun sebagai seorang guru ia juga menjadi sosok orang tua yang memberikan kasih dan pengayoman bagi setiap anak didiknya. Keenam, Terkait dengan tugas dan peran guru dalam melaksanakan pembelajaran maka yang perlu di persiapkan oleh seorang guru adalah: penguasaan, pemahaman dan pengembanagan materi, penggunaan metode yang tepat, efektif dan senantiasa melakukan 


\section{Daniel Supriyadi}

pengembangannya, serta menumbuhkan kepribadian kepada peserta didik (Mujtahid, 2011, p. 53). Ketujuh, Guru sebagai Evaluator Untuk meningkatkan mutu pendidikan maka sebagai seorang guru perlu melaksanakan evaluasi bagi kegiatan pembelajaran yang dilakasanakan. Seorang guru harus terus-menerus melakukan evaluasi baik dalam maupun luar sekolah, guna meningkatkan mutu pendidikan yang lebih baik (Mujtahid, 2011).

\section{REKOMENDASI PENGEMBANGAN PENELITIAN}

Penulis berharap hasil penelitian ini dapat bermanfaat bagi gereja, lembaga pendidikan dan terlebih kepada keluarga. Kiranya saran atau kritik dapat diberikan kepada penulis oleh semua pembaca agar dikesempatan selanjutnya penulis dapat lebih lagi dalam mengembangkan kemampuan yang telah diberikan oleh Tuhan. Penelitian ini masih dapat dikembangkan dengan melihat relevansi penelitian ini, dengan fakta-fakta di tahun-tahun selanjutnya, oleh orang-orang yang mau menguji atau mengembangkannya. Kemudian, penulis juga berharap kiranya penelitian ini dapat menjadi referensi dari penulis-penulis berikutnya yang sedang menulis tentang topik-topik seputar pembahasan yang ada pada artikel ini.

\section{KESIMPULAN}

Pelayanan Sekolah Minggu merupakan pelayanan yang memiliki posisi yang sama dengan semua pelayanan yang ada di gereja. Pelayanan Sekolah Minggu adalah pelayanan yang tidak mudah karena memerlukan ketekunan dan kesabaran yang ekstra dalam pelaksanaannya. Adanya Sekolah Minggu di gereja dapat menciptakan generasi penerus gereja, maka dari itu pengajaran kekristenan yang diberikan harus benar-benar tertanam dalam diri anak sejak dini. Sekolah Minggu dapat telah mengimplementasikan Best Practice atau Praktik Terbaik dalam pengelolaan pengajaran Pendidikan Agama Kristen di sekolah minggunya. Dimana dengan penyelenggaraan Pendidikan Agama Kristen yang baik maka akan dihasilkan murid-murid yang baik dan menjadi generasi penerus bagi gereja.

Implementasi Best Practice PAK dalam Sekolah Minggu didasari dalam mencakup ruang kelas, alokasi waktu, kegiatan, bahan ajar, metode yang dipakai, fasilitas yang diberikan serta pembiayaan. Semua aspek tersebut sudah di kerjakan sesuai dengan unsu-unsur yang membentuk sistem pembelajaran. Untuk itu gereja perlu memperhatikan pelayanan Sekolah Minggu yaitu dengan menyelenggarakan pendidikan Sekolah Minggu dengan praktik terbaik dalam rangka menyiapkan generasi penerus gereja. Sekolah Minggu merupakan cikal bakal 


\section{Daniel Supriyadi}

pendidikan bagi penerus gereja. Dalam melaksanakan kegiatan Sekolah Minggu sebaiknya memenuhi beberapa aspek kegiatan Sekolah Minggu. Beberapa aspek dalam kegiatan Sekolah Minggu yaitu, Sekolah Minggu sebagai pusat pendidikan non-formal, pekabaran Injil, alat penjangkau, dan penyalur berkat.

\section{REFERENSI}

Arifianto, Y. A., Budiyana, H., \& Purwoto, P. (2021). Model dan Strategi Pembelajaran Yesus berdasarkan Injil Sinoptik dan Implementasinya bagi Guru Pendidikan Agama Kristen. Harati: Jurnal Pendidikan Kristen, 1(1), 1-17.

Baskoro, H., \& Hermawati, C. O. (2011). Jurnalisme untuk Sekolah Minggu. Penerbit Andi.

Boehlke, R. R. (2009). Sejarah Perkembangan Pikiran dan Praktek Pendidikan Agama Kristen. BPK Gunung Mulia.

Darmawan, I. P. A. (2016). Peran Gereja dalam Pendidikan Nasional. Jurnal Simpson: Jurnal Teologi Dan Pendidikan Agama Kristen, 1(2), 205-216.

Edlin, R. J. (2015). Hakikat Pendidikan Kristen. BPK Gunung Mulia.

Elisabeth. (2009). Pembelajaran PAK Pada Anak Usia Dini. Bina Media Informasi.

Enklaar, I. H., \& Homrighausen, E. G. (2011). Pendidikan Agama Kristen. Jakarta: BPK Gunung Mulia.

Groome, T. H. (2017). Christian Religious Education - Pendidikan Agama Kristen (6th ed.). Gunung Mulia.

Homrighausen, E. ., \& Enklaar, I. . (2018). Pendidikan Agama Kristen. BPK Gunung Mulia.

Kadarmanto, \& Ruth S. (2005). Tuntunan ke jalan yang benar. BPK Gunung Mulia.

Leo, S. (2008). Panduan Sukses Mengelola \& Mengajar Sekolah Minggu. Penerbit Andi.

Lie, P. (2003). Mereformasi Sekolah Minggu: 8 Kiat Praktis Menjadikan Sekolah Minggu Berpusat pada Anak,. Andi Offset.

Mamangkey, J., Sinsuw, A., Karouw, S., \& Tuturoong, N. (2013). Aplikasi E-Visual Aid Sekolah Minggu Berbasis Android. Jurnal Teknik Informatika, 2(2). https://doi.org/10.35793/jti.2.2.2013.2113

Mujtahid. (2011). Pengembangan Profesi Guru. UIN-Maliki Press Malang.

Nainggolan, J. M. (2006). Menjadi guru agama Kristen: suatu upaya peningkatan mutu dan kualitas profesi keguruan. Generasi Info media.

Nuhamara, D. (2009). Pembimbing PAK, Pendidikan Agama Kristen. Jurnal Info Media. 
Prajnamitra, T., Suparti, H., Wahyuni, S., \& Sentot Purwoko, P. (2020). Studi Eksplanatori Dan Konfirmatori Nasehat Rasul Paulus Tentang Kedewasaan Penuh Berdasarkan Efesus 4:1 - 32 Di Kalangan Guru Pendidikan Agama Kristen Sekolah Dasar ( SD ) Se - Kota Surakarta. Jurnal Pendidikan Agama Kristen (JUPAK), 1(1), 1-20. https://doi.org/10.52489/jupak.v1i1.7

Purwoto, P., Budiyana, H., \& Arifianto, Y. A. (2020). Landasan Teologis Pendidikan Kristen dalam Perjanjian Baru dan Relevansinya bagi Pendidikan Kristen Masa Kini.

DIDAKTIKOS: Jurnal Pendidikan Agama Kristen, 3(1), 34-48.

Setiawaty, T. (2017). Penerapan Best Practice Pada Manajemen Pembelajaran Praktek Smk Pika Semarang Dalam Mempersiapkan Lulusan Siap Kerja Dan Berdaya Saing Global. Innovation of Vocational Technology Education, 9(2). https://doi.org/10.17509/invotec.v9i2.4879

Setiyowati, E. P., \& Arifianto, Y. A. (2020). Hubungan Kompetensi Pedagogik Guru dan Prestasi Belajar Siswa pada Mata Pelajaran Pendidikan. SIKIP Jurnal Pendidikan Agama Kristen, 1(2), 78-95.

Sijabat, B. S. (1994). Strategi Pendidikan Kristen: Suatu Tinjauan Theologis-Filosofis. In Yogyakarta: Yayasan Andi.

Simanjuntak, J. M. (2014). Implikasi Konsep Dan Desain Kurikulum Dalam Tugas Pembinaan Warga Jemaat. Jurnal Jaffray, 12(2), 251-272.

Sitanggang, E., Daliman, M., Suparti, H., \& Wahyuni, S. (2020). Implementasi Pengajaran Rasul Paulus Tentang Nasehat Hidup Bersatu Dan Merendahkan Diri Seperti Kristus Berdasarkan Filipi 2:1-30 Dikalangan Gembala Sidang GPdI Se-Jawa Tengah. Jurnal Pendidikan Agama Kristen (JUPAK), 1(1), 21-37.

https://ejurnal.sttkadesiyogyakarta.ac.id/index.php/jupak/article/view/4

Sudjana, N. (2009). Dasar-dasar Proses Belajar Mengajar. SINAR BARU GENSINDO.

Sumiyatiningsih, D. (2012). Mengajar Dengan Kreatif dan Menarik: Buku Panduan Mengajar PAK. ANDI.

Syatra, N. Y. (2013). Desain Relasi Efektif Guru dan Murid. In Jogjakarta: Bukubiru.

Tong, S. (1995). Arsitek Jiwa II. LRII.

Tung, K. Y. (2015). Menuju sekolah Kristen impian masa kini. In Isu-isu Filsafat, Kurikulum, Strategi dalam Pelayanan Sekolah Kristen. Penerbit Andi.

Umrati, \& Wijaya, H. (2020). Analisis Data Kualitatif Teori Konsep dalam Penelitian Pendidikan. Sekolah Tinggi Theologia Jaffray.

Vidyarini, T. N., \& Priyowidodo, G. (2014). Endangered Media Berbasis Multimedia Untuk Pemberdayaan Guru-Guru Sekolah Minggu (Sunday School). SHARE: "SHaring Action - REflection," 2(1), 10-15. https://doi.org/10.9744/share.2.1.10-15

Waspada, I. (2012). Analisa Best Practice Service Level Management (Slm) Cisco Menggunakan Kriteria Kelengkapan Dari Thomas Schaaf. Jurnal Masyarakat 
Informatika, 1(2). https://doi.org/10.14710/jmasif.1.2.1-10

Zaluchu, S. E. (2020). Strategi Penelitian Kualitatif dan Kuantitatif Di Dalam Penelitian Agama. Evangelikal: Jurnal Teologi Injili Dan Pembinaan Warga Jemaat, 4(1), 28-38. https://doi.org/10.46445/ejti.v4i1.167 